\title{
OPENNESS OF FORESTS AND FOREST LAND IN THE BOSNIA AND HERZEGOVINA ENTITY REPUBLIC OF SRPSKA
}

\author{
OTVORENOST ŠUMA I ŠUMSKOG ZEMLJIŠTA \\ U BOSNI I HERCEGOVINI, ENTITETU REPUBLICI SRPSKOJ
}

\author{
S. DRAŽIĆ ${ }^{1}$, M. DANILOVIĆ2 ${ }^{2}$ D. STOJNIĆ ${ }^{3}$, V. BLAGOJEVIĆ ${ }^{4}$, R. LUČIĆ ${ }^{5}$
}

\begin{abstract}
Summary
The focus of this paper is on the description of the openness of primary forest traffic infrastructure in the Republic of Srpska. The data were collected using Garmin Oregon 600 GPS devices across the entire territory of state forests, managed by the Public Enterprise „Šume Republike Srpske”, and the recorded traces were compared and corrected by orthophoto snapshots with a $0.50 \mathrm{~m}$ resolution. The tools used for the processing of collected data were software ESRI ArcGIS 10.2 and Quantum GIS 16.2. In addition, the analysis covers all forest roads that pass through state forests that can be used for forest management and enable the movement of trucks. Public roads are only taken as an overview of openness of this category of roads and forest openness is shown by forest categories. The analyses included $843,466.00$ ha out of the total of 1,002,056.00 ha of state-owned forests. The final aim of this analysis was to obtain a clear insight into the quantitative status of primary forest traffic infrastructure in the Republic of Srpska. The data were collected during 2016. Based on the analysis, the total density of the network of primary forest traffic infrastructure for the research area was $9.28 \mathrm{~m} / \mathrm{ha}$ without public roads, i.e. $11.21 \mathrm{~m} / \mathrm{ha}$ with public roads. In addition, density of the network of primary forest traffic infrastructure was determined separately for each category of forests, and the highest density of forest road network was found in forest plantations $(11.57 \mathrm{~m} / \mathrm{ha}$ or $14.82 \mathrm{~m} / \mathrm{ha}$ with public roads) and high forests with natural regeneration $(11.13 \mathrm{~m} / \mathrm{ha}$ or $12.49 \mathrm{~m} / \mathrm{ha}$ with public roads).
\end{abstract}

KEY WORDS: Forest roads, Forest opening, Density of primary forest traffic infrastructure, a register of primary forest roads, GIS, GPS, Republic of Srpska

\section{INTRODUCTION AND PREVIOUS RESEARCH UVOD I PRETHODNA ISTRAŽIVANJA}

The construction of a forest road network is considered a key element for successful forest management (Krč \& Beguš, 2013). A well planned, designed, constructed and maintained system of forest roads is essential to facilitate forest management and protection of natural resources (Nasiri \& Lotfalian, 2012). Open forests are gradually equipping the planned road network and forest stocks (Tucek and Suchomel, 1998). Primary forest roads provide access to forests for the production of wood assortments,

\footnotetext{
${ }^{1}$ MSc Srđan DRAŽlĆ, Research Develop and Project Centre, Grčka 21,78000 Banja Luka, BiH, srdjandrazic@gmail.com

${ }^{2}$ Milorad DANILOVIĆ, DSc, full professor, University of Belgrade - Faculty of Forestry, The Chair of Forest Utilization, Kneza Višeslava 1, 11000 Belgrade, Serbia,

${ }^{3}$ MSc Dušan STOJNIĆ, University of Belgrade - Faculty of Forestry, The Chair of Forest Utilization, Kneza Višeslava 1, 11000 Belgrade, Serbia,

${ }^{4}$ Velibor BLAGOJEVIĆ DSc., Research Develop and Project Centre, Grčka 21,78000 Banja Luka, BiH

${ }^{5}$ Radovan LUČIĆ DSc., Research Develop and Project Centre, Grčka 21,78000 Banja Luka, BiH,
} 
but also for the needs of forests, monitoring, research, recreation, fire protection and other purposes (Eastaugh \& Molina, 2011, Stefanović et al. 2016, Laschi et al. 2016). Planning a network of truck roads is preceded by a detailed analysis of the current qualitative and quantitative state of roads, and above all determines the spatial distribution of truck roads (Pentek et al. 2005; Lotfalian et al. 2008; White et al. 2010; Krč \& Beguš, 2013; Danilović \& Stojnić, 2014). The analysis of current spatial distribution reveals the part of the forest which does not allow access to the use of existing roads (Pellegrini, 2012). An analysis of the existing primary forest traffic infrastructure consists of a series of operations and procedures. Its task is to determine the quality, quantity and possible deficiencies of the existing road network, while it is also the first stage in the planning and optimization of a forest road network (Pentek et al. 2005).

Primary forest traffic infrastructure in the Republic of Srpska consists of forest roads that go through the forest and can be used for forest management. According to the Law on Public Roads (Official Gazette of RS, No. 89/13), forest track roads belong to the category of unclassified roads, together with rural, agricultural and industrial paths and roads on embankments for flood protection, access roads and others. In recent years, various studies on the state of the network of forest roads and perspectives of their development were carried out in the Republic of Srpska (Ljubojević, 2010; Potočnik et al. 2013; Danilović \& Ljubojević, 2013; Petković et al. 2015; Dražić, 2016; Marić, 2016). During their research, the authors obtained a variety of information about the openness of forests and forest land at disposal. However, the information were mainly obtained on the basis of assessment or incomplete and unreliable evidence. So, Potočnik et al. 2009 reported that the density of the network of truck roads in Bosnia and Herzegovina and the Republic of Srpska was $8.7 \mathrm{~m} / \mathrm{ha}$ in 2009, while three years later (Potočnik et al. 2012) the reported density of the network of truck roads was as low as $6.0 \mathrm{~m} /$ ha. However, in the report on the analysis of the forestry sector in Bosnia and Herzegovina $(F A O, 2015)$ the density of the network of forest truck roads in the Republic of Srpska is $9.05 \mathrm{~m} / \mathrm{ha}$.

In 2016, an inventory of primary forest traffic infrastructure in the area of Public Enterprise „Šume Republike Srpske” was produced in order to gain a clear insight into the quantitative status of the network of truck roads in the Republic of Srpska. The inventory of primary forest traffic infrastructure was implemented using handheld GPS devices, and the data were processed using GIS softwares. Although it is clear that handheld GPS devices are not designed for accurate measurements, especially in forest conditions (Abdi et al. 2012), it was concluded that they could be used for the mapping of forest roads, since forest roads are mostly open areas where trees are removed. The development of the existing forest road cadastre is a prerequisite for conducting analyses and obtaining quality forest opening programs. Since the network of forest roads is dynamic and subject to constant changes, it is very important to regularly update the database (Talebi et al. 2015).

\section{RESEARCH AREA PODRUČJE ISTRAŽIVANJA}

The research was conducted in the territory of the Republic of Srpska, one of the two entities in Bosnia and Herzegovina. According to the Cadastre of forests (PFE, 2015), the total area of forests and forest land owned by the Republic of Srpska is 1,002,055.00 ha, and the total area of forests and privately owned forest land is $300,329.00 \mathrm{ha}$.

Table 1. An overview of forest areas and forest land by forest categories

Tablica 1. Pregled površina šuma i šumskog zemljišta prema kategorijama šuma

\begin{tabular}{|c|c|}
\hline Forest categories & ha \\
\hline 1000 - High forests with natural regeneration & $469,167.00$ \\
\hline \multicolumn{2}{|l|}{ Visoke šume s prirodom obnovom } \\
\hline 2000 - High degraded forests & $19,611.00$ \\
\hline \multicolumn{2}{|l|}{ Visoke degradirane šume } \\
\hline $\begin{array}{l}3000 \text { - Forest plantations } \\
\text { Šumske kulture }\end{array}$ & $55,347.00$ \\
\hline 4000 - Coppice forests & $206,642.00$ \\
\hline \multicolumn{2}{|l|}{ Panjače } \\
\hline $\begin{array}{l}5000 \text { - Surfaces suitable for afforestation and } \\
\text { forest management }\end{array}$ & $168,851.00$ \\
\hline \multicolumn{2}{|l|}{ Površine podesne za pošumljavanje } \\
\hline $\begin{array}{l}6000 \text { - Surfaces unsuitable for afforestation and } \\
\text { forest management }\end{array}$ & $63,108.00$ \\
\hline \multicolumn{2}{|l|}{ Površine nepodesne za pošumljavanje } \\
\hline 7000 - Usurpation & $19,329.00$ \\
\hline \multicolumn{2}{|l|}{ Uzurpacije } \\
\hline TOTAL - Ukupno & $1,002,055.00$ \\
\hline
\end{tabular}

User forests and forest land owned by the Republic of Srpska are managed by the Public Enterprise „Šume Republike Srpske", within 26 forest management units (FMU) and karst areas managed by the Center for karst management with headquarters in Trebinje. Areas of the national parks "Kozara" (3,530.00 ha) and "Sutjeska" (17,214.00 ha) belong to forests and forest land owned by the Republic of Srpska, while industrial plantations cover an area of $7,383.00 \mathrm{ha}$. In this paper, we analyzed an area of $843,466.00$ hectares managed by 26 forest management units (FMU) without the Brčko District. These areas are not included in the analysis because forests and forest land in this region have a different purpose, which could have an impact on the results. 


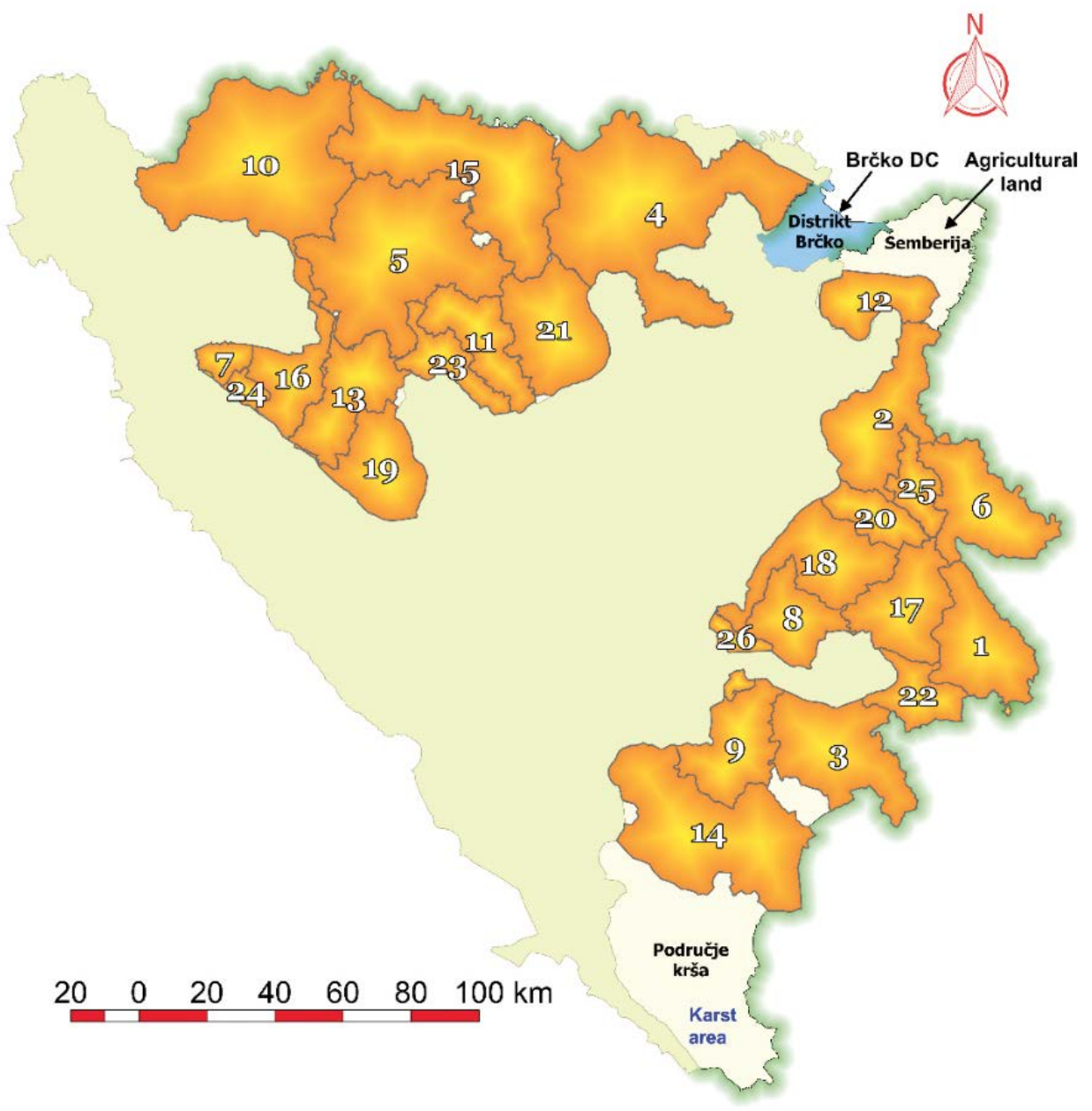

LEGEND (FMU-s):

1 višegradsko

2 vlaseničko

3 gornje drinsko

4 dobojsko-derventsko

5 donje vrbasko

6 donje drinsko

7 petrovačko

8 jahorinsko

9 kalinovičko

10 kozaračko

11 kotorvaroško

12 majevičko

13 mrkonjićko

14 nevesinjsko-gatačko

15 posavsko

16 ribničko

17 rogatičko

18 romanijsko

19 srednje- vrbasko

20 hanpjesačko

21 usorsko-ukrinsko

22 čajničko

23 čemerničko

24 istočno- drvarsko

25 milićko

26 trnovsko

Figure 1: A map of forest areas in the Republic of Srpska

Slika 1: Pregledna karta šumsko-gospodarskih područja Republike Srpske

\section{MATERIALS AND METHODS MATERIJALI I METODE}

As outlined in the previous section, the research was carried out in the area of 26 forest economic units. Forest engineers made Tracklogs using GARMIN Oregon 600 handheld GPS devices. All tracklogs were recorded in the form of polyline composed of $10 \mathrm{~m}$-long segments, while the starting and ending points of each tracklog, as well as intersection locations were recorded as points. The recording was carried out in one pass, and the speed of movement of the vehicle during the recording was in line with the road category. The software used for data processing was GIS, ESRI ArcGIS 10.2 and Quantum GIS 2.16 „Nødebo“. The recorded track

Table 2. Technical characteristics of forest roads (UNDP, 2008)

Tablica 2. Tehničke karakteristike šumskih cesta (UNDP, 2008)

\begin{tabular}{|c|c|c|c|c|}
\hline \multirow{2}{*}{$\begin{array}{l}\text { Road category } \\
\text { Kategorija puta }\end{array}$} & \multicolumn{4}{|c|}{ The main forest road - Glavna šumska cesta } \\
\hline & $\begin{array}{l}\text { Lowland } \\
\text { Ravničarski }\end{array}$ & $\begin{array}{l}\text { Between lowland and hilly } \\
\text { Brežuljkasti }\end{array}$ & $\begin{array}{c}\text { Hilly } \\
\text { Brdoviti }\end{array}$ & $\begin{array}{l}\text { Mountain } \\
\text { Planinski }\end{array}$ \\
\hline Speed - brzina $(\mathrm{km} / \mathrm{h})$ & 60 & 40 & 30 & 25 \\
\hline Min Radius & 85 & 40 & 20 & 15 \\
\hline Min Radius (serpent.) & 40 & 15 & 15 & 12 \\
\hline Long. Grade - uzdužni nagib & \multicolumn{4}{|c|}{$6 \%-8 \%$} \\
\hline Track width - širina kolovoza & \multicolumn{4}{|c|}{$3.0 \mathrm{~m}-3.5 \mathrm{~m}$} \\
\hline Shoulder width - širina bankine & \multicolumn{4}{|c|}{$0.5 \mathrm{~m}-0.75 \mathrm{~m}$} \\
\hline $\begin{array}{l}\text { roadway construction - } \\
\text { Kolovozna konstrukcija }\end{array}$ & \multicolumn{4}{|c|}{$\begin{array}{c}\text { „Mac Adam" or "Telford" Depending on the category of soil. - "Makadam" ili "Telford" U ovisnosti } \\
\text { od kategorije zemljišta. }\end{array}$} \\
\hline
\end{tabular}


logs of truck roads were further controlled using orthophoto images with a $0.50 \mathrm{~m}$ resolution.

Primary forest traffic infrastructure that was taken for analysis, represents all forest truck roads that allow movement of trucks with and without trailers, regardless of the pavement condition. The following table provides technical standards that must be met by forest roads in the Republic of Srpska. All public roads that pass through the forest or its boundary which can be used for forestry purposes were included in the research. From the aspect of categorizing public roads (The law on public roads of RS, 2013), such roads are all local and regional highways and most of the arterial highways, but not fast roads and highways.

Density of the network of forest roads was calculated using the formula:

$$
R D=\frac{L[m]}{A[h a]}
$$

$\mathrm{RD}$ - density of the forest roads network $\mathrm{m} / \mathrm{ha}$,

L - Calculation length of forest roads,

A - area.

The length of forest roads was calculated according to the following criteria. Entire length was taken into account for roads that pass through forest land. Half the length of the road was taken into account for roads that go to the edge of forest land or up to $300 \mathrm{~m}$ from the edge of forest land provided that they can be used for transport. In addition, roads coming perpendicular to the forest land were considered in the length of up to $500 \mathrm{~m}$ (Šikić et al., 1989).

In addition to the analysis of density of the network of truck roads, the paper presents a ten-year construction rate of truck roads by forest regions. The dynamics of truck road construction was obtained from the systematization of data of the "Research Development and Project Center" from Banja Luka, which designs truck roads for the purpose of the Public Enterprise „Šume Republike Srpske” and controls derivative works.

Since there is no precise analysis of the optimal density of truck roads in the Republic of Srpska, similar relief surfaces from neighboring countries were used as parameter in this case. The analysis of forest roads according to the relief characteristics of Croatia, which are similar to the characteristics in Bosnia, revealed that minimum openness required for the management of forests in RS starts from $15 \mathrm{~m} /$ ha, while the optimal value is about $20 \mathrm{~m} / \mathrm{ha}$ (Šikić et al., 1989). The analysis of forest openness also included these parameters.

\section{RESEARCH RESULTS REZULTATI ISTRAŽIVANJA}

According to the categorization of roads, the roads that open forest regions in the Republic of Srpska are classified into public and forest roads. The total length of roads in the Republic of Srpska for the analyzed area amounts to $9,453.73$ kilometers. The length of public roads is $1,628.16$ kilometers or $17.22 \%$, and of forest roads $7,825.57 \mathrm{~km}$ or $82.78 \%$. Based on these data and the methodology applied to calculate the density of the network of truck roads, the result is that the average density of the primary forest traffic infrastructure in the Republic of Srpska is $9.28 \mathrm{~m} / \mathrm{ha}$ and $11.21 \mathrm{~m} / \mathrm{ha}$ of public roads.

An exceptionally low openness is evident in the "majevičko" forest management unit, whose openness amounts to 1.19

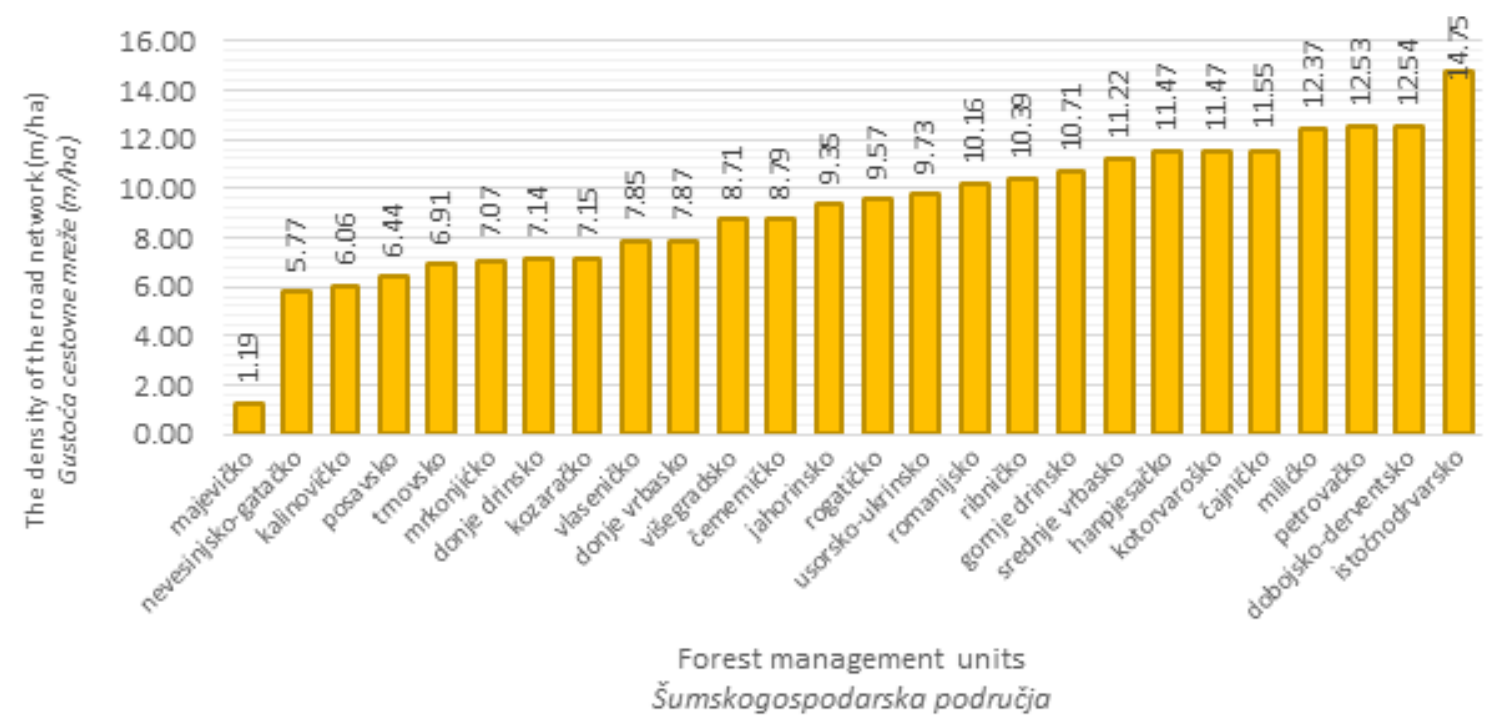

Figure 2: The average density of primary forest traffic infrastructure by forest regions $(\mathrm{m} / \mathrm{ha})$

Slika 2: Prosječna gustoća primarne šumske prometne infrastrukture po šumsko-gospodarskim područjima (m/ha) 


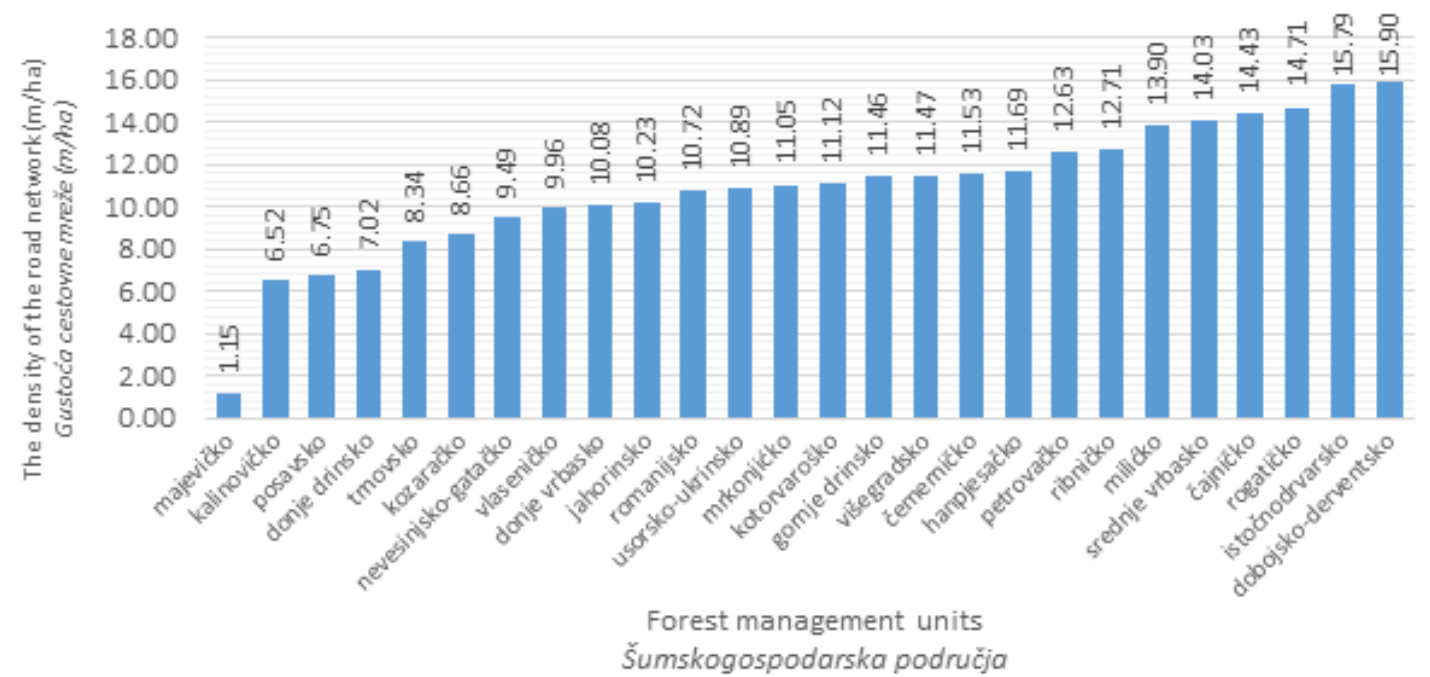

Figure 3: The average density of primary forest traffic infrastructure in high forests with natural regeneration by forest regions $(\mathrm{m} / \mathrm{ha})$ Slika 3: Prosječna gustoća primarne šumske prometne infrastrukture u visokim šumama sa prirodnom obnovom po šumskogospodarskim područjima (m/ha)

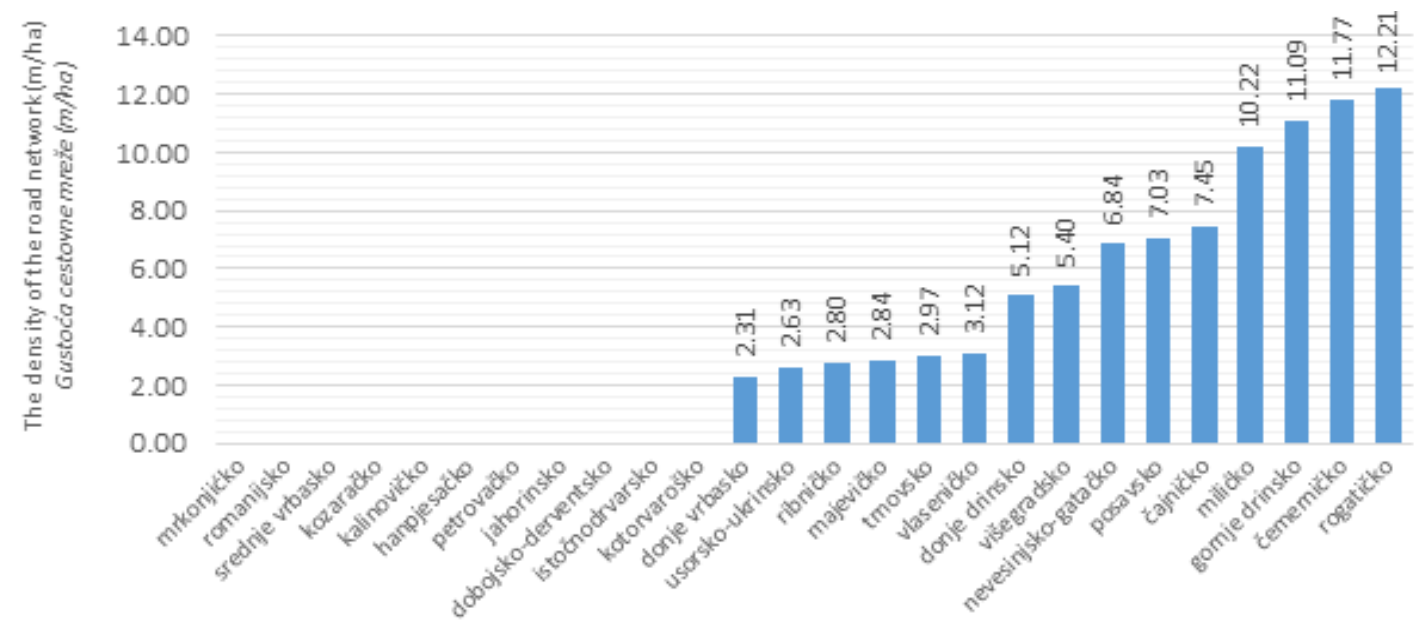

Figure 4: The average density of primary forest traffic infrastructure in high degraded forests by forest regions $(\mathrm{m} / \mathrm{ha})$

Slika 4: Prosječna gustoća primarne šumske prometne infrastrukture u visokim degradiranim šumama po šumsk-ogospodarskim područjima (m/ha)

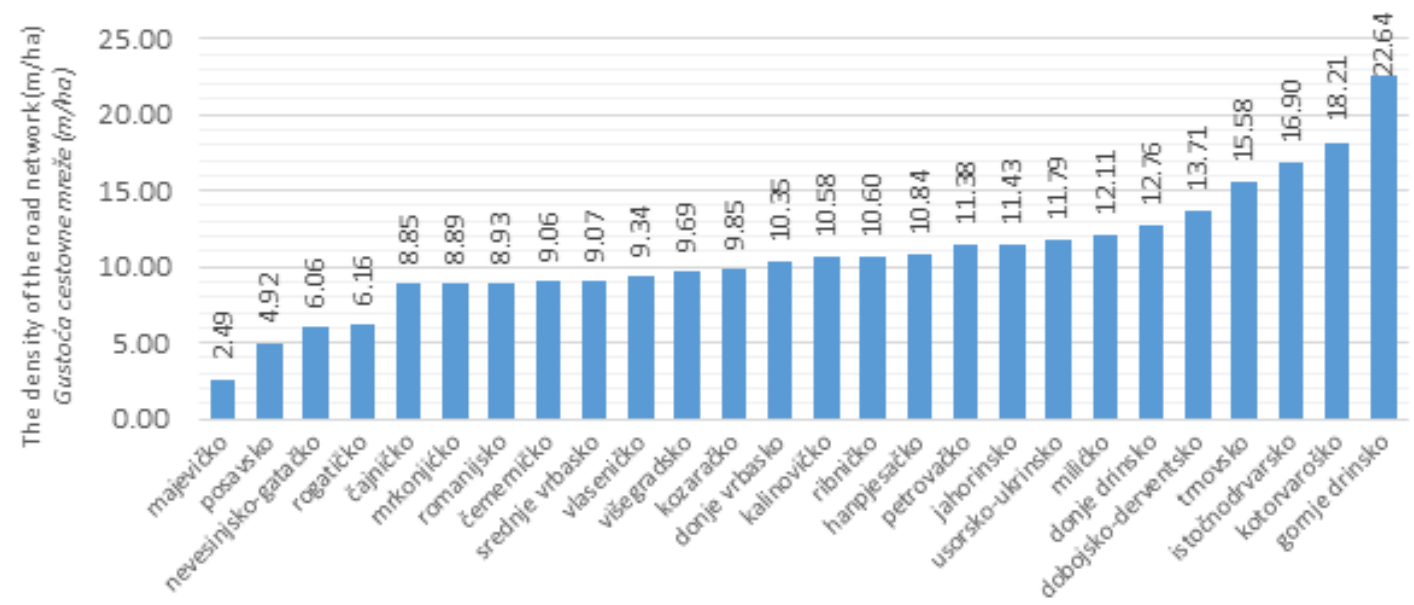

Forest management units

Šumskogospodarska područja

Figure 5: The average density of primary forest traffic infrastructure in forest plantations by forest regions $(\mathrm{m} / \mathrm{ha})$

Slika 5: Prosječna gustoća primarne šumske prometne infrastrukture u šumskim kulturama po šumsko-gospodarskim područjima (m/ha) 


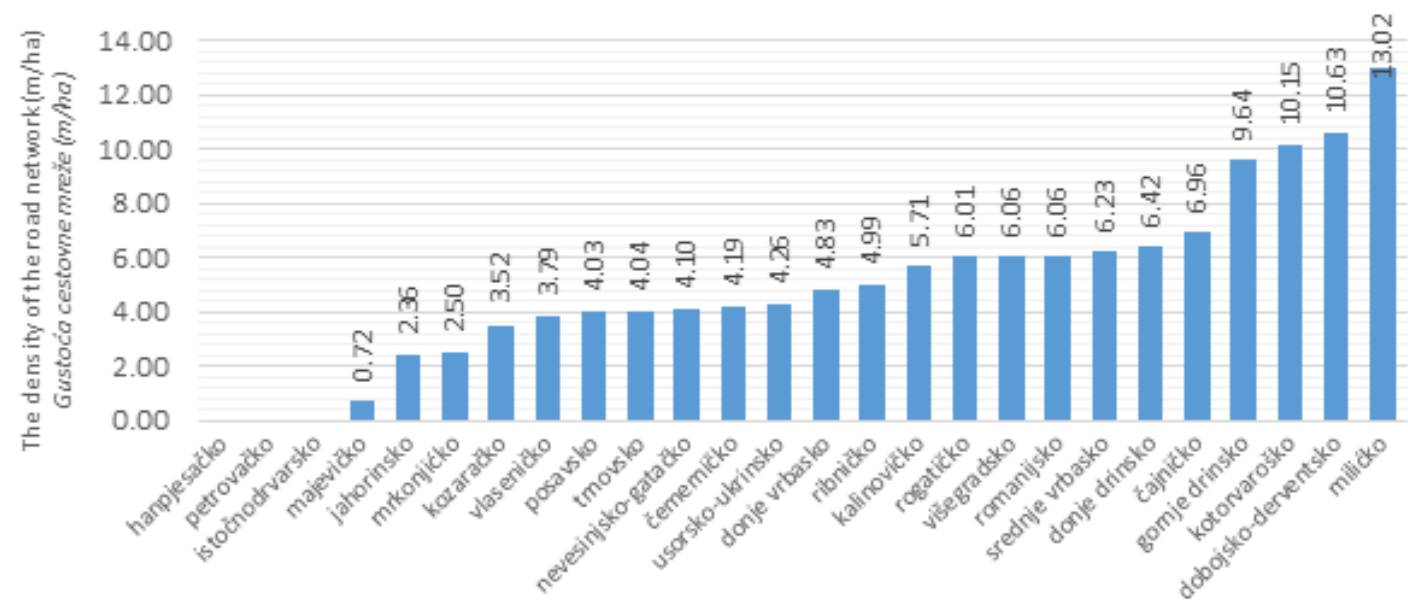

Forest management units

Šumskogospodarska područja

Figure 6: The average density of primary forest traffic infrastructure in coppice forests by forest regions $(\mathrm{m} / \mathrm{ha}$ )

Slika 6: Prosječna gustoća primarne šumske prometne infrastrukture u izdanačkim šumama po šumsko-gospodarskim područjima (m/ha)

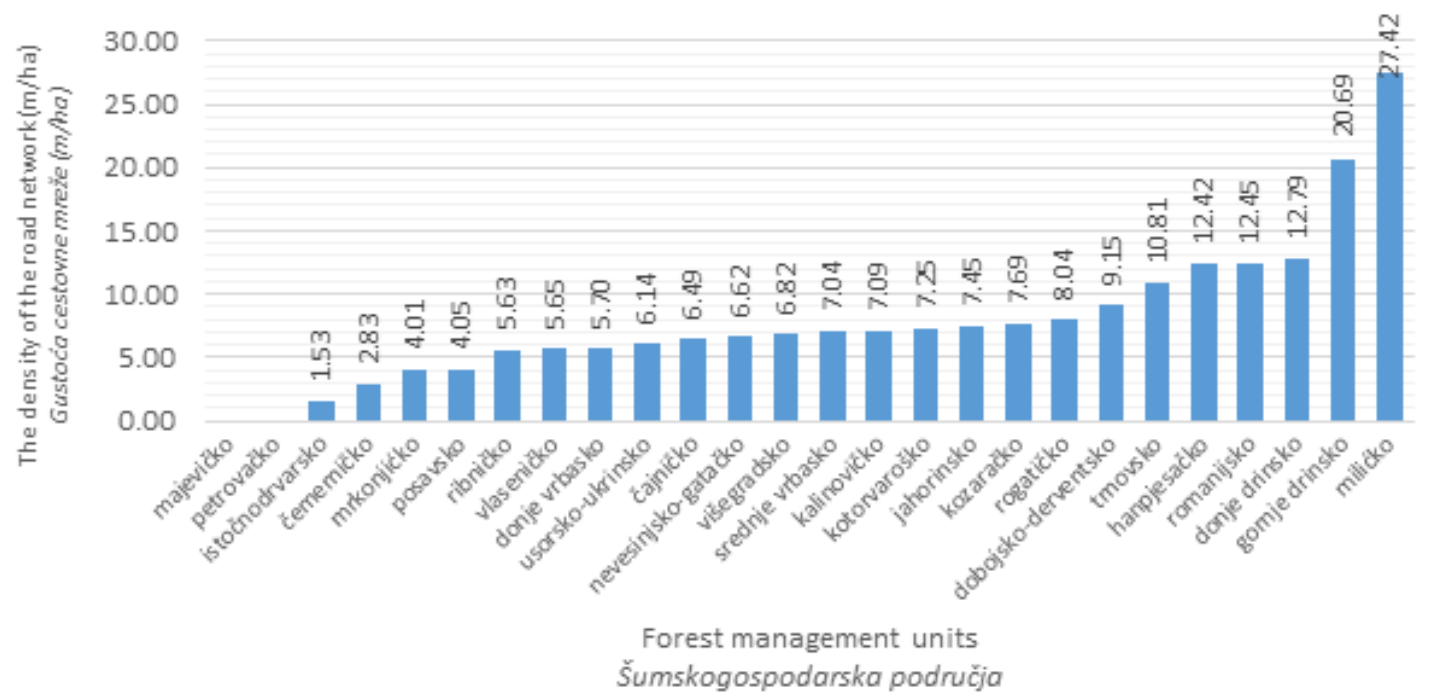

Figure 7: The average density of primary forest traffic infrastructure in areas suitable for reclamation and afforestation by forest regions (m/ha) Slika 7: Prosječna gustoća primarne šumske prometne infrastrukture na površinama podesnim za pošumljavanje po šumsko-gospodarskim područjima (m/ha)

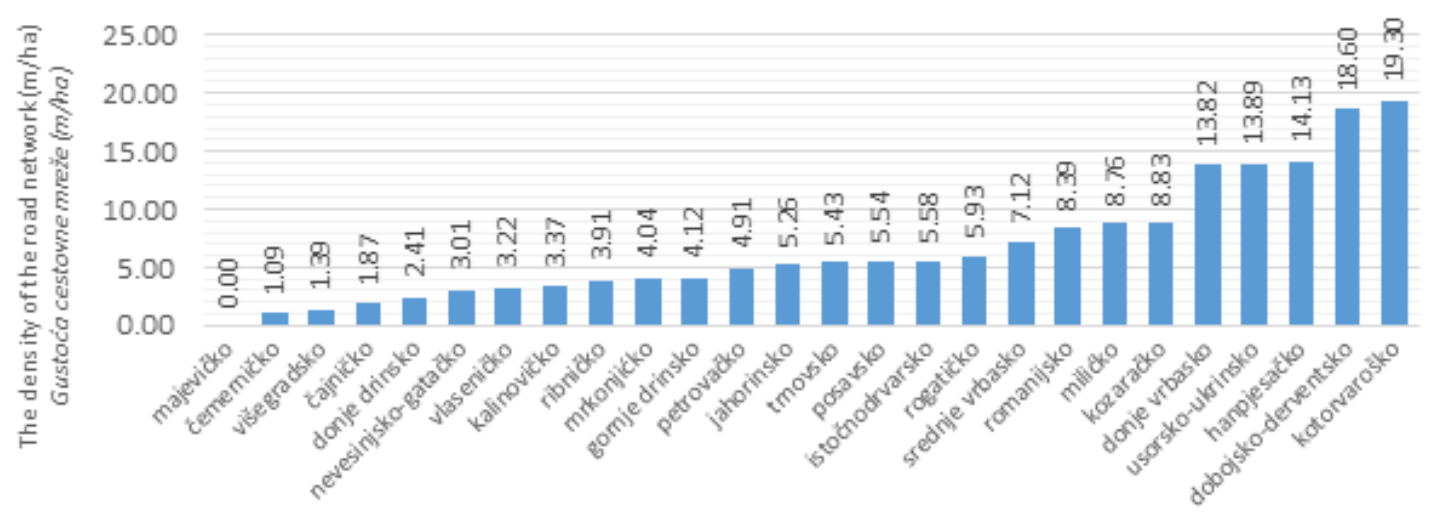

Forest management units

Šumskogospodarska područja

Figure 8: The average density of primary forest traffic infrastructure in areas unsuitable for reclamation and afforestation by forest regions ( $\mathrm{m} / \mathrm{ha}$ ) Slika 8: Prosječna gustoća primarne šumske prometne infrastrukture na površinama nepodesnim za pošumljavanje po šumskogospodarskim područjima (m/ha) 
Table 3: Summary of the density of primary forest traffic infrastructure by forest categories Tablica 3: Sumarna gustoća primarne šumske prometne infrastrukture po kategorijama šuma

\begin{tabular}{|c|c|c|c|c|c|c|}
\hline $\begin{array}{l}\text { Forest Categories } \\
\text { Kategorija šuma }\end{array}$ & $\begin{array}{l}\text { Forest roads } \\
\text { Šumske ceste } \\
\text { (m) }\end{array}$ & $\begin{array}{l}\text { Public roads } \\
\text { Javne ceste } \\
\text { (m) }\end{array}$ & $\begin{array}{c}\text { Total } \\
\text { Ukupno } \\
\text { (m) }\end{array}$ & $\begin{array}{c}\text { Forest roads } \\
\text { Šumske ceste } \\
\text { (m/ha) }\end{array}$ & $\begin{array}{l}\text { Public roads } \\
\text { Javne ceste } \\
\text { (m/ha) }\end{array}$ & $\begin{array}{l}\text { Total } \\
\text { Ukupno } \\
\text { (m/ha) }\end{array}$ \\
\hline 1000 & $5,216,803.63$ & $634,635.90$ & $5,851,439.54$ & 11.13 & 1.35 & 12.49 \\
\hline 2000 & $149,467.02$ & $28,251.71$ & $177,718.73$ & 7.46 & 1.41 & 8.87 \\
\hline 3000 & $612,340.99$ & $172,077.27$ & $784,418.26$ & 11.57 & 3.25 & 14.82 \\
\hline 4000 & $997,367.18$ & $449,262.26$ & $1,446,629.44$ & 5.86 & 2.64 & 8.51 \\
\hline 5000 & $530,322.80$ & $162,924.81$ & $693,247.60$ & 8.05 & 2.47 & 10.53 \\
\hline 6000 & $207,025.43$ & $149,203.18$ & $356,228.61$ & 4.38 & 3.16 & 7.54 \\
\hline \multirow[t]{2}{*}{7000} & $112,244.43$ & $31,802.72$ & $144,047.15$ & 5.99 & 1.70 & 7.69 \\
\hline & $7,825,571.48$ & $1,628,157.85$ & $9,453,729.33$ & 9.28 & 1.93 & 11.21 \\
\hline
\end{tabular}

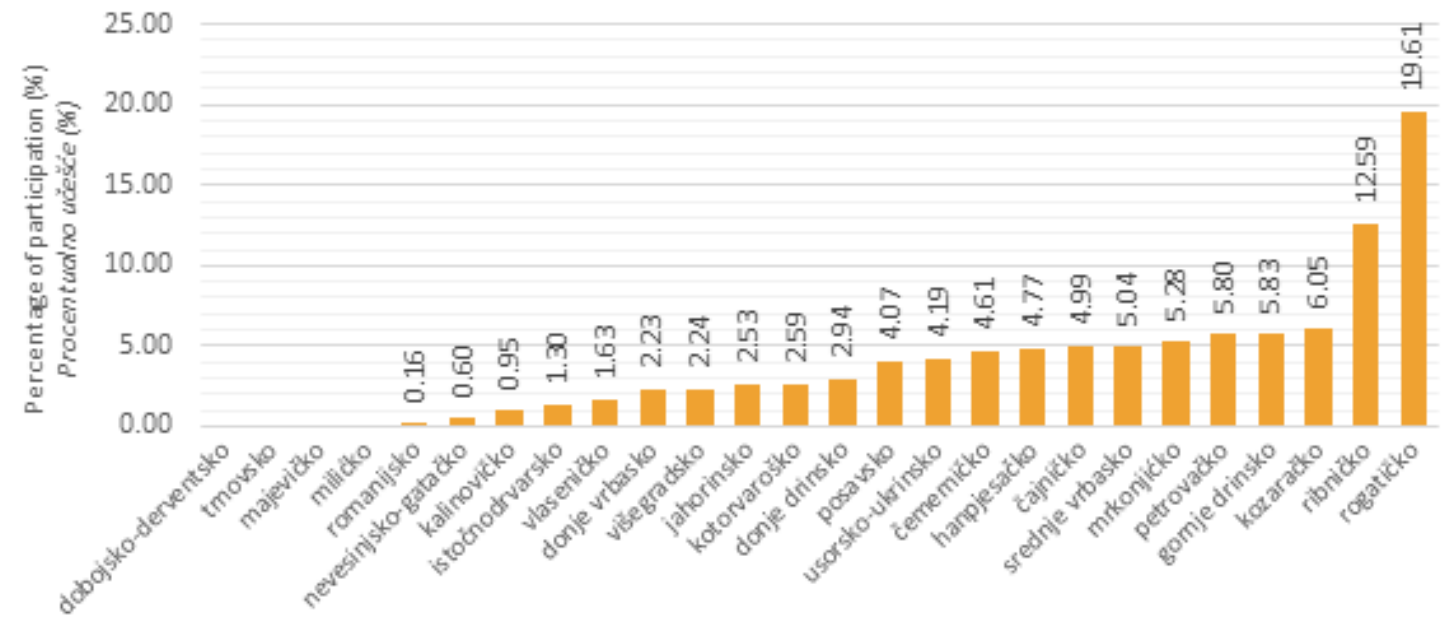

Forest management units Šumskogospodarska područja

Figure 9: Percentage of participation in road construction by forest regions for the period 2006-2016. Slika 9: Procentualno učešće izgradnje cesta po šumskogospodarskim područjima za period 2006-2016.

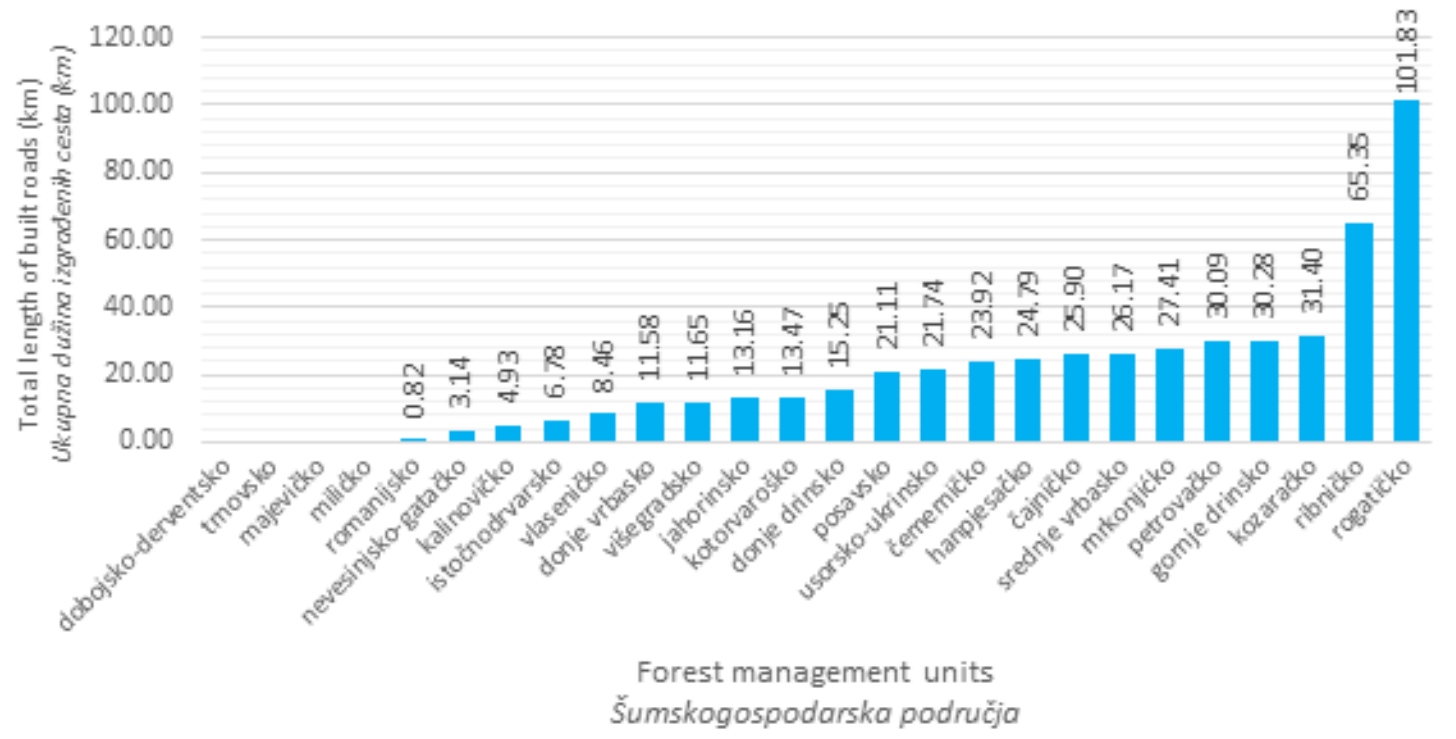

Figure 10: Total length of built roads by forest management areas for the period 2006-2016.

Slika 10: Ukupna dužina izgrađenih cesta po šumsko-gospodarskim područjima za period 2006-2016. 


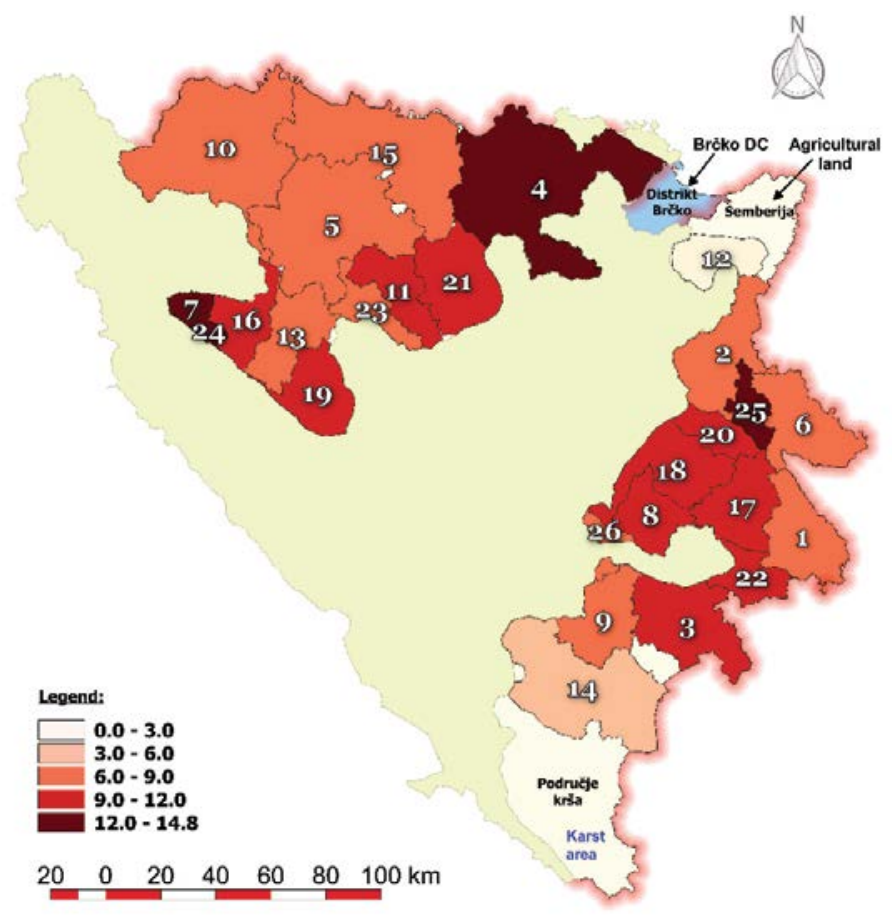

Figure 11: The average density of primary forest traffic infrastructure in the Republic of Srpska Slika 11: Prosječna gustoća primarne šumske prometne infrastrukture u Republici Srpskoj

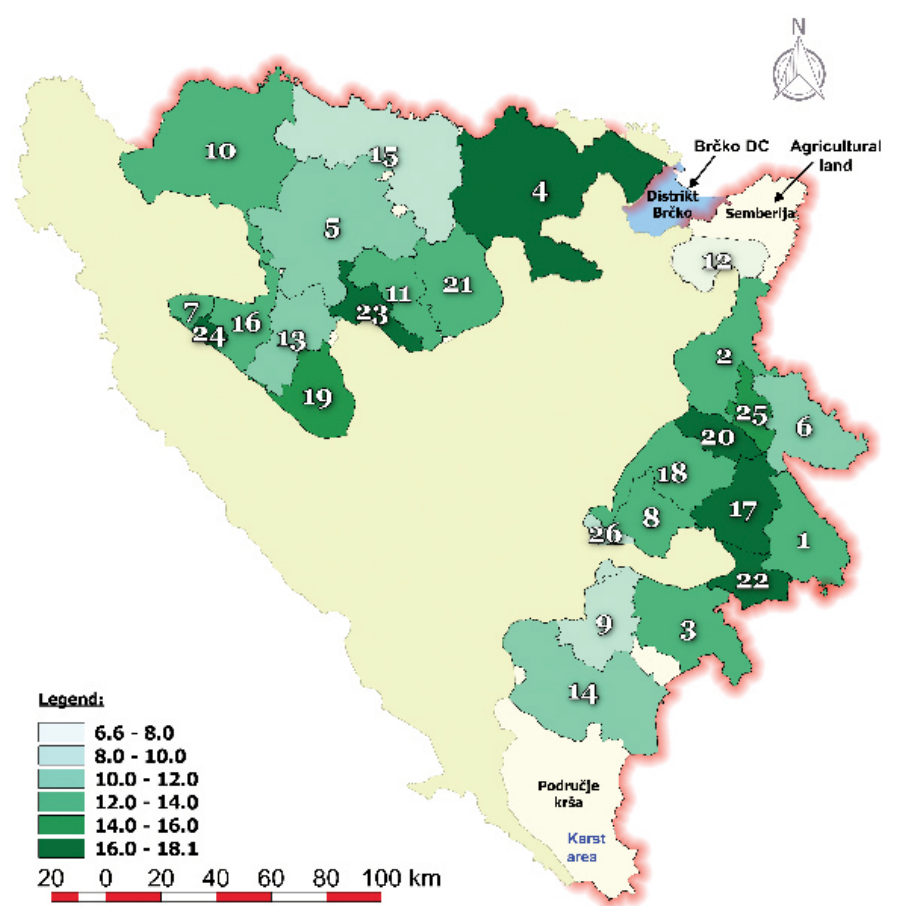

Figure 12: The average density of primary forest traffic infrastructure in high forest with natural regeneration $(\mathrm{m} / \mathrm{ha})$ Slika 12: Prosječna gustoća primarne šumske prometne infrastrukture u visokim šumama s prirodnom obnovom (m/ha)

$\mathrm{m} / \mathrm{ha}$. In this area, a large percentage of the forest is protected due to drinking water, so there is no intensive forest road construction and forest exploitation in this area. The municipality of Bijeljina finances the protected parts of the fo- rest. The openness of public roads in terms of transport assortments is $8.61 \mathrm{~m} / \mathrm{ha}$.

According to the data of the "Research Development and Project Center” from Banja Luka for the period from 2006 


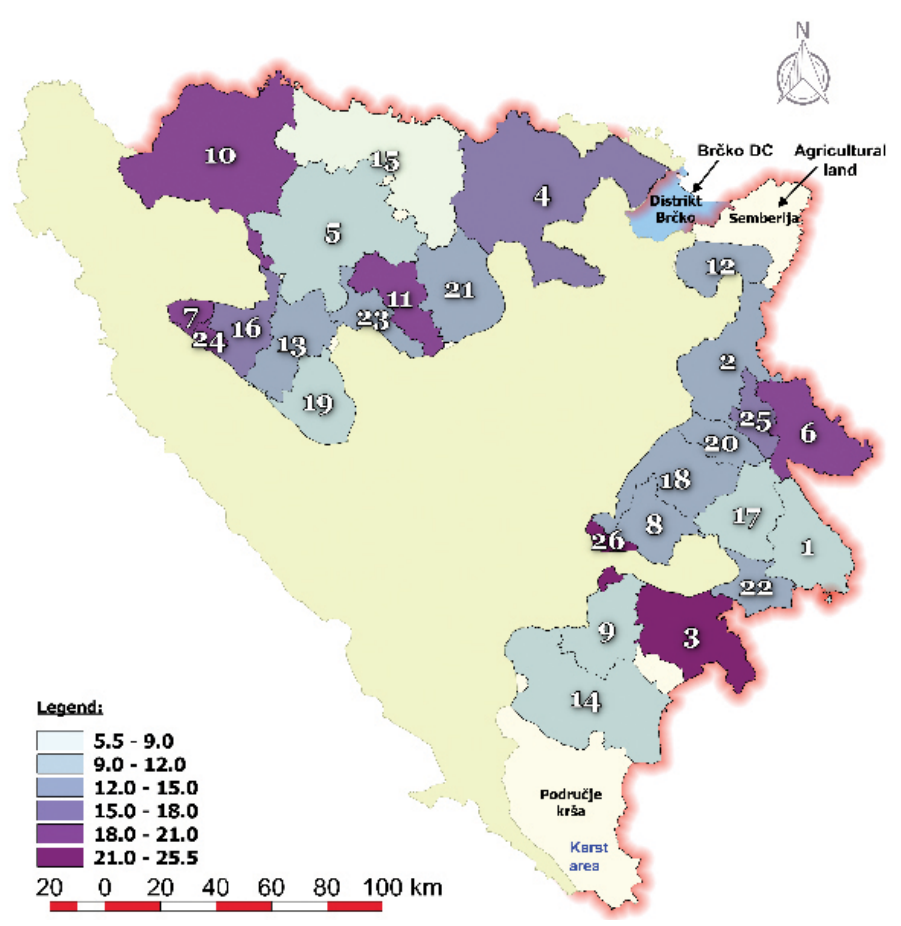

Figure 13: The average density of primary forest traffic infrastructure in forest plantations $(\mathrm{m} / \mathrm{ha})$ Slika 13: Prosječna gustoća primarne šumske prometne infrastructure u šumskim kulturama (m/ha)

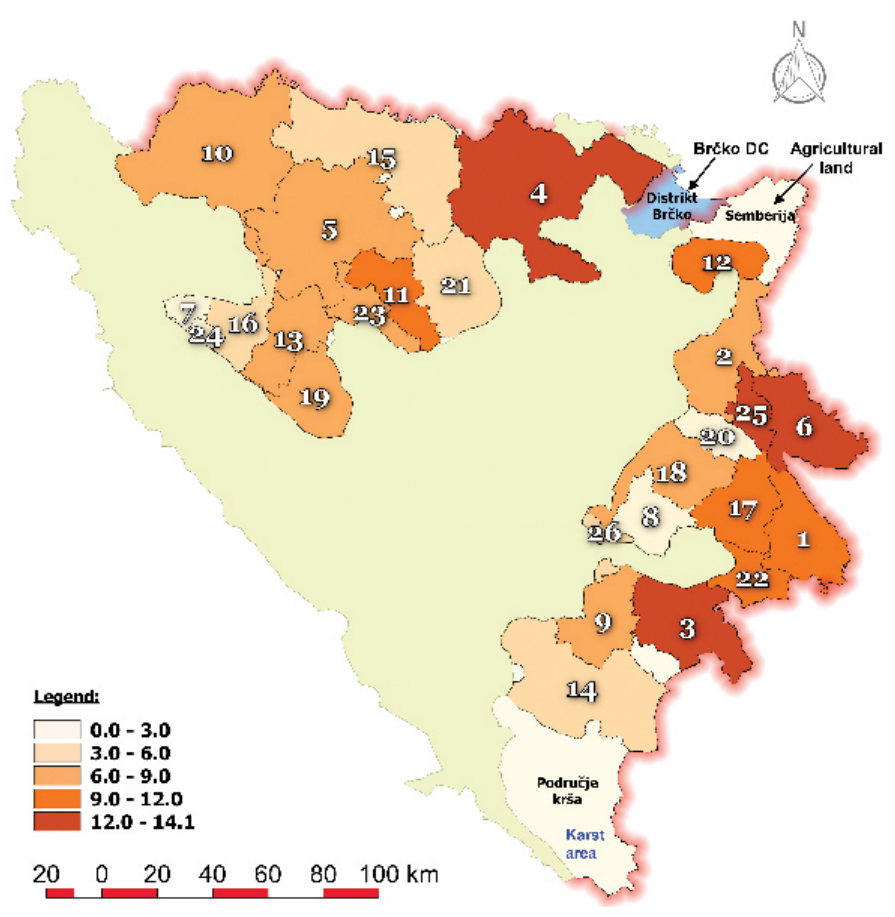

Figure 14: The average density of primary forest traffic infrastructure in coppice forests $(\mathrm{m} / \mathrm{ha})$ Slika 14: Prosječna gustoća primarne šumske prometne infrastrukture u panjačama (m/ha)

to 2016, 47.20 kilometers of forest truck roads are built on average in the Republic of Srpska each year. The total length of newly designed and constructed forest truck roads for this period reached $519.21 \mathrm{~km}$. The average cost of con- struction of forest truck roads in the period from 2006 to 2016 amounted to $61,694.00 \mathrm{BAM} / \mathrm{km}(31,541.00 € / \mathrm{km})$.

Figure 9 shows the percentage share of road construction for each of the forest management areas for the period 


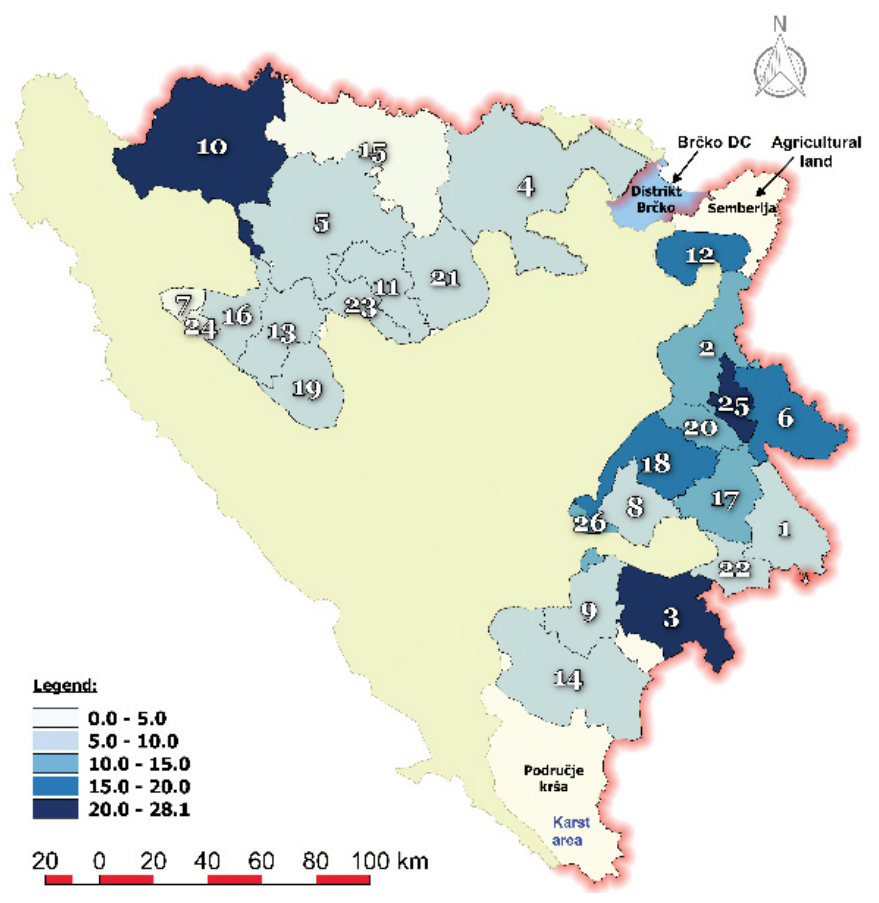

Figure 15 The average density of primary forest traffic infrastructure in forests suitable for reclamation and afforestation ( $\mathrm{m} / \mathrm{ha}$ ) Slika 15: Prosječna gustoća primarne šumske prometne infrastrukture u šumama podesnim za pošumljavanje (m/ha)

shown. Forest management units "ribničko" and "rogatičko" achieve the best financial results, so they are able to invest more financial resources than others.

Figure 10 shows the amount or length of constructed roads for each forest area in relation to the total road construction in the exploration area for the shown period.

\section{DISCUSSION RASPRAVA}

The combination of GPS and GIS technology represents a global trend with an inexhaustible range of applications when it comes to collecting and analyzing spatial information (Drosos et al. 2014) and a fast, efficient and cost-effective method of forest roads inventory (Gumus \& Acar, 2003). Due to possible defects occurring during the recording of forest roads, the precision of the GPS device and the signal quality, further analysis of the recorded data is necessary. Çalişkan \& Karahalil (2017) applied GPS tracking and formed a database on every road, while Lepoglavec et al. (2015) made a correction of recorded data using orthophotos, in addition to recording a forest path track with a GPS device in one pass. Pentek et al. (2003) recommend recording the so-called "Feedback Methods, i.e., two-way shooting paths to minimize errors.
As already mentioned in this paper, a network of roads was created in the forests owned by Public Enterprise „Šume Republike Srpske" in 2016. Based on the analysis of the quantitative conditions in the network of truck roads in the Republic of Srpska, the density of primary forest traffic infrastructure is $9.28 \mathrm{~m} / \mathrm{ha}$ and for public roads $11.21 \mathrm{~m} / \mathrm{ha}$. According to the above density of the network of truck roads, Republic of Srpska lags behind developed countries of Western Europe, in which the density of forest road networks reaches over $45 \mathrm{~m} / \mathrm{ha}$ (Sokolović \& Bajrić, 2009), but not so much behind the countries of the region. By comparison, the total length of roads used for forestry in Macedonia is $13,263.00 \mathrm{~km}$, of which $3,326.00 \mathrm{~km}$ are public roads and $9,937.00 \mathrm{~km}$ are truck roads, which makes the density of truck road network of $13.43 \mathrm{~m} / \mathrm{ha}$ (Trajanov et al. 2015). Based on data from 2009, the density of the network of primary forest traffic infrastructure in the Federation of $\mathrm{BiH}^{\star}$ (without the Herzegovina-Neretva Canton) was $10.9 \mathrm{~m} / \mathrm{ha}$ (Sokolović \& Bajrić, 2009). Pentek et al. (2014) reported that the density of forest roads in Croatian lowland regions was $9.05 \mathrm{~m} / \mathrm{ha}$, in hilly areas $11.26 \mathrm{~m} / \mathrm{ha}$, and $15.43 \mathrm{~m} / \mathrm{ha}$ in the mountains, while in the karst area reached about $4.81 \mathrm{~m} / \mathrm{ha}$. Analyzing the network of forest and public roads that were used for forestry in Slovenia, Krč \& Beguš (2013) point to the density of the road network of $24.8 \mathrm{~m} / \mathrm{ha}$. If we take only 
forest roads into account, the network density is $10.6 \mathrm{~m} / \mathrm{ha}$, while in Austria it is as high as $45 \mathrm{~m} / \mathrm{ha}$ (Ghaffarian \& Stampfer, 2007). When we talk about the network of truck roads in Serbia, there are still no precise data on their quantitative and qualitative status (Danilović \& Stojnić, 2014). The road network density in Bulgaria is $7.90 \mathrm{~m} / \mathrm{ha}$ (Stoilov et al. 2014), and in Romania $13.73 \mathrm{~m} / \mathrm{ha}$ (Bereziuc et al. 2014). In Czech Republic it amounts to $18.0 \mathrm{~m} / \mathrm{ha}$ (Žáček \& Klč, 2008), $10.1 \mathrm{~m} / \mathrm{ha}$ in Ukraine (without public roads $7.8 \mathrm{~m} /$ ha) (Styranivsky et al. 2011), and in Slovakia it reaches 20.1 $\mathrm{m} / \mathrm{ha}$ (Ambrušová et al. 2013).

Despite significant investment in the construction of primary forest traffic infrastructure in recent years, the density of the network in the Republic of Srpska is still not at a satisfactory level. In the past 11 years in the area of forests owned by the Republic of Srpska almost $519 \mathrm{~km}$ of truck roads and about $47.20 \mathrm{~km}$ per year were built. However, in addition to an underdeveloped network of truck roads, a major drawback is also the relatively low quality of the network of truck roads, and uneven density of the road network by forest regions. The dynamics of the construction of truck roads for a ten-year management period is envisaged in planning documents for all forest management areas, but looking at the results, it can be concluded that not everyone adhered to the dynamics of road construction, while in the forest region Doboj - Derventa, Trnovo, Lopare and Milići areas, forest truck roads have not been built at all.

Figure 11 shows the average openness of forest management units. It can be observed that higher openness can be found in forest management areas with high quality forests and those belonging to the hilly - mountainous belt. The top open areas are: 20 - petrovačko; 4 - dobojsko-derventsko; 25 - milićko and 24 - istočnodrvarsko. These are mostly hilly and mountain regions dominated by high forests with natural regeneration. The least opened areas are: 15 - posavsko, 14 - nevesinjsko - gatačko, 9 - kalinovičko and 12 - majevičko. The areas with a large share of high forests have higher openness, because the costs of forest road construction can be compensated by wood assortment production. Areas without a significant share of high forests have extremely low openness.

\section{CONCLUSIONS}

\section{ZAKLJUČCI}

Based on data from the field and the processing of data collected from over $843,000.00$ hectares in 26 forest management units which belong to different relief areas and over 9,450.00 kilometers of forest roads and public roads recorded, the density of forest road network of $9.28 \mathrm{~m} / \mathrm{h}$ a was found in forests managed by the Public Enterprise „Šume Republike Srpske", while in public roads it amounted to $11.21 \mathrm{~m} / \mathrm{ha}$. The newly built roads increased the density of primary forest traffic infrastructure by $0.62 \mathrm{~m} / \mathrm{ha}$. With this dynamics of construction, minimum openness would be achieved in 60 years including public roads, while minimum openness for primary forest truck roads would be achieved in 100 years. Only one forest area can be considered minimally open, representing about $1.48 \%$ of the total area of state forests in the Republic of Srpska. It is important to intensify the construction of primary forest road trucks, and especially focus on forest areas with almost no construction. The lack of financial resources and poor quality of forests in some forest management units result in inadequate openness. It is also necessary to carry out a more detailed analysis of specific impact factors for this area in order to determine the optimum. It is necessary that planning documents or specific studies elaborate on all the factors affecting forest openness, in order to achieve the optimum density of the forest road network for different relief conditions.

The data on the density of forest road network in the Republic of Srpska represent an exceptional value, obtained from the recording of the current state of the forest road network and systematization of the data collected, which represents the first study of this type in such a wide area. A completed inventory of forest roads represents the basis for developing strategies and plans for further development of the forest road network in the Republic of Srpska.

\section{REFERENCES}

\section{LITERATURA}

- Abdi, E., S.R. Slsakht, L. Goushbor, H. Soufl, 2012: Accuracy assessment of GPS and surveying technique in forest road mapping. Annals of Forest Research, Vol. 55(2): 309-317

- Ambrušová, L., D. Halaj, J. Ilavský, J. Marttila, 2013: Atlas of the forest sector in Slovakia. Working Papers of the Finnish Forest Research Institute 257, pg. 38

- Bajrić, M., D. Pičman, Dž. Sokolović, S. Gurda, 2011: Conversion of skid trails with a longitudinal slope up to $12 \%$ into truck access roads. Works of the Faculty of Forestry, University of Sarajevo, No. 1: 85-100.

- Bereziuc, R., V. Alexandru, V. Ciobanu, E.C. Musat, A-E. Dumitrascu, C. Antoniade, J. Visan, 2014: The Density Index of ForestRoad Network Managed by the National Forest Administration (R.N.P.). Proceedings of the Biennial International Symposium - Forest and Sustainable Development. Transilvania University Press, Brasov, 2015, pg. 196-203.

- Çalişkan, E., U. Karahalil, 2017: Evaluation of forest road network and determinig timber extraction system using GIS: A case study in Anbardag planning unit. Šumarski list, 3-4 (2017): 163171

- Danilović, M., D. Ljubojević, 2013: Forest opening with a secondary road network. Bulletin of Faculty of Forestry University of Banja Luka, 108: 25-38

- Dražić, S., 2016: Forest opening in the economic unit "Dimitor" in the forestry management unit "Lisina" Mrkonjić Grad. Master thesis. The University of Belgrade, Faculty of Forestry, pg. 81 
- Drosos, V.C., A.G. Liampas, K.G. Doukas, 2014: Digital surveying and mapping of forest road network for development of a GIS-tool for the effective protection and management of natural ecosiystems. Published in SPIE Proceedings Vol. 9229: Second International Conference on Remote Sensing and Geoinformation of the Environment (RSCy2014), 12 August 2014, doi: $10.1117 / 12.2069660$

- Eastaugh, C.S., D. Molina, 2011: Forest road networks: metrics for coverage, efficiency and convenience. Australian Forestry, Vol. 74(1): 54-61.

- FAO 2015: The Forest Sector in Bosnia and Herzegovina - Preparation of IPARD Forest and Fisheries Sector Reviews in Bosnia and Herzegovina. Regional Office for Europe and Central Asia, FAO, pg. 153.

- Ghaffarian, M.R., K. Stampfer, 2007: Optimum road spacing of forwarding operations: A case study in Soutern Austria. In Proceedings of Austro2007/FORMEC 07: Meeting the Needs of Tomorrows Forests - New Developments in Forest Engineering, October 7 - 11, 2007, Vienna and Heiligenkreuz - Austria

- Gumus, S., H. Acar, 2003: Building of forest road database by GPS/GIS techniques for Turkish forestry. Austro2003: High Tech Forest Operations for Mountainous Terrain, October 5-9, 2003, Schlaegl - Austria

- JPŠ, “Šume Republike Srpske”, 2015: Cadastre of forest and forest land.

- Krč, J., J. Beguš, 2013: Planning Forest Opening with Forest Roads. Croatian Journal of Forest Engineering 34(2013)2: 217 228

- Laschi, A., F. Neri, N. Brachetti Montorselli, E. Marchi, 2016: A Methodological Approach Exploiting Modern Techniques for Forest Road Network Planning. Croatian Journal of Forest Engineering 37(2016)2: 319-331

- Lepoglavec, K., T. Pentek, I. Papa, M. Šporčić, M. Landekić, H. Nevečerel, 2015: Influence of existing secondary forest road network on the selection of timber extraction technologies at the tactical level of planning. Bulletin of Faculty of Forestry, supplement issue, University of Belgrade - Faculty of Forestry (63-74). DOI: $10.2298 / G S F 15 S 1063 \mathrm{~L}$

- Ljubojević, D. 2010: Forest opening in the economic unit „Kozara-Mlječanica“, Master thesis. The University of Belgrade, Faculty of Forestry pg. 36.

- Lotfalian, M., Y. Kooch, N. Sarikhani, 2008: Effective Factors in Determination Optimal Density of Forest Road Netwoek. Asian Journal of Scientific Research, 1(4): 470-475.

- Marić, D. 2016: Analysis of forest opening by road network in the forest management unit "Čemernica" Kneževo. Master thesis. The University of Belgrade, Faculty of Forestry, pg. 59

- Nasiri, M., M. Lotfalian, 2012: Programming and Forest Road Planning. Journal of Ecology and Environmental Sciences, Vol 3(2): 68-73.

- Petković, V., D. Marčeta, S. Španjić, M. Kosović, 2015: Determination of skidding distance with GIS in the lowland and hilly terrain conditions. Bulletin of Faculty of Forestry University of Banja Luka 23: 5-14

- Pellegrini, M., 2012: Support tools for planning and management of a forest road network. Dipartimento Terrirorio e Sistemi AgroForestali, Doctoral thesis.

- Pentek, T., D. Pičman, A.P.B. Krpan, T. Poršinsky, 2003: Inventory of primary and secondary forest communications by the use of GPS in Croatian mountainous forest. In Proceedings of Austro2003: High Tech Forest Operations for Mountainous Terrain, October 5-9, 2003, Schlaegl - Austria
- Pentek, T., D. Pičman, H. Nevečerel, 2004: The mean wood skidding distance. Šumarski List, 9-10: 545-558.

- Pentek, T., H. Nevečerel, T. Ecimović, K. Lepoglavec, I. Papa, Ž. Tomašić, 2014: Strategic planning of forest roads in Republic of Croatia - a breakdown of the existing situation as a basis for future activities. Nova mehanizacija šumarstva 35(2014): 63-78

- Pentek, T., D. Pičman, I. Potočnik, H. Nevečerel, P. Dvorščak, 2005: Analysis of an existing forest road network. Croatian Journal of Forest Engineering, 26(1): 39-50.

- Pičman, D., T. Pentek, 1998: Relative openness of the forest area and its use in the construction of the forest fire-prevention roads, Šumarski list 1-2: 19-30.

- Potočnik, I., V. Petković, D. Marčeta, D. Ljubojević, 2013: Determination of optimal density of forest roads network in Prosara. Bulletin of Faculty of Forestry University of Banja Luka, No. 18: 45-56

- Potočnik, I., S. Ljubojević, V. Petković, D. Marčeta, 2009: State of the art principles of forest road planning. Bulletin of Faculty of Forestry University of Banja Luka, No. 10: 1-13

- Sokolović, D., M. Bajrić, 2009: Forest Transportation Infrastructure in the Federation of Bosnia and Herzegovina, Nova mehanizacija šumarstva, Vol 34: 39-50.

- Stefanović, B., D. Stojnić, M. Danilović, 2016: Multi-criteria forest road network planning in fire-prone environment: a case study in Serbia. Journal of Environmental Planning and Management, 59:5, 911-926, DOI:10.1080/09640568.2015.1045971.

- Stoilov S., T. Krumov, N. Uchikov, 2014: Study of forest road network in Central Rhodoppes mountains (in Bulgarian with English apstract). Mechanics, Transport, Communications - Academic journal, Vol. 12(3/3): VIII-1 - VIII-8

- Styranivsky, O., Y. Hromyak, Y. Styranivsky, 2011: Argumentation of Optimum Road Density in the Forests of Ukraine. In Proceedings of FORMEC 2011 - Pushing the boundaries with research and innovation in forest engineering, October 9-13, 2011, Graz, Austria

- Šikić, D., B. Babić, D. Topolnik, D. Knežević, D. Božičević, Ž. Švabe, I. Piria, S. Sever, 1989: Tehnički uvjeti za gospodarske ceste. Znanstveni savjet za promet JAZU, Zagreb, p. 1-40.

- Talebi, M., B. Majnounian, E. Abdi, F.B. Teherani, 2015: Developing a GIS database for forest road management in Arasbaran forest, Iran. Forest Science and Technology, 11(1): 27-35, DOI: 10.1080/21580103.2014.957351

- Trajanov Z., Lj. Nestorovski, P. Trajkov 2015: Development and perspective of the forest road infrastructure in the Republic of Macedonia. Bulletin of Faculty of Forestry, supplement issue, University of Belgrade - Faculty of Forestry (141-148), DOI:10.2298/GSF15S1141T

- Tucek J., J. Suchomel, 1998: Technological Requirements for the Location of Forest Roads in Slovak Conditions, in Proceedings of the Seminar on Environmentally Sound Forest Roads and Wood Transport, Sinaia, Romania, 17-22 June 1996.

- Law on public roads. Official Gazette of the Republic of Srpska No. $89 / 13$

- Žáček, J., P. Klč, 2008: Forest transport roads according to natural forest regions in the Czech Republic. Journal of Forest Science. Vol. 54(2): 73-83

- UNDP, 2008: Guidelines for forest roads. Srebrenica region recovery program, pg. 20

- White, R.A., B.C. Dietterick, T. Mastin, R. Strohman, 2010: Forest Roads Mapped Using LiDAR in Steep Forested Terrain. Remote Sensing Vol 2: 1120-1141, DOI: 10.3390/rs2041120 


\section{Sažetak}

Radi potrebe unaprjeđenja mreže cesta u Republici Srpskoj, u ovome radu su prikazani određeni rezultati. Dinamiku izgradnje cesta i otvaranja šuma prate velike oscilacije, a posebice stagnacija početkom devedesetih godina. Izgradnja cesta u Republici Srpskoj nastavljena je vrlo slabo do 2006 godine, kada se krenulo intenzivno s projektiranjem i izgradnjom šumskih kamionskih cesta do danas. U ovome razdoblju na prostoru Republike Srpske izgrađeno je $519 \mathrm{~km}$ cesta, ili prosječno 47.20 $\mathrm{km}$ godišnje. S obzirom da ne postoji jasna analiza optimalne gustoće kamionskih cesta u Republici Srpskoj, u ovom slučaju su kao parameter poslužila slična reljefna područja iz okruženja. Pritom minimalna otvorenost koja je potrebna za gospodarenje šumama u RS uzeta je vrijednost od $15 \mathrm{~m} / \mathrm{ha}$, dok je optimalna oko $20 \mathrm{~m} / \mathrm{ha}$. Na osnovi ovih parametara učinjena je i analiza otvorenosti šuma. Otvorenost šuma šumskim kamionskim cestama iznosi $9.28 \mathrm{~m} / \mathrm{ha}$. Mnogi autori prikazali su otvorenost šuma, uključujući i javne ceste. Glede toga, i u ovome radu prikazana je otvorenost od $11.21 \mathrm{~m} / \mathrm{ha}$. Otvorenost javnim cestama možemo promatrati u smislu značenja ne samo za transport šumskih drvnih sortimenata, nego i za zaštitu šuma od požara i monitoring šuma, kao i za prijevoz radnika i opreme do šuma za potrebe izvođenja radova na pošumljavanju, uzgoju i korišćenju šuma. Gustoća šumskih kamionskih cesta za radoblje od 2006. do2016. godine je uvećana za $0.62 \mathrm{~m} / \mathrm{ha}$. Ovom dinamikom izgradnje cesta minimalna otvorenost bi se dostigla za 100 godina. Otvorenost šuma kreće se od $1.19 \mathrm{~m} / \mathrm{ha}$, pa sve do $14.75 \mathrm{~m} / \mathrm{ha}$. Svega jedno šumsko-gospodarsko područje (istočnodrvarsko) može se svrstati u minimalno otvoreno, što predstavlja 1.48\% od ukupne površine državnih šuma Republike Srpske. Šumskogospodarsko područje “majevičko" ima najnižu otvorenost. Na ovome prostoru velika površina šuma je zaštićena kao vodozahvat pitke vode u općini Bijeljina, i na ovome prostoru nije dozvoljena intenzivnija eksploatacija šuma, pa samim tim i izgradnja šumskih kamionskih cesta. S obirom da je ovo područje malo površinom, ono nema veliki utjecaj na ukupnu otvorenost šuma i šumskog zemljišta. Iz rezultata ovoga istraživanja. dolazi se do zaključka, kao i u entitetu Federacija Bosne i Hercegovine, da su najvažnija pretpostavka i uvjet za unaprjeđenje šumske prometne infrastrukture i u Republici Srpskoj financijska sredstva. Nedostatak financijskih sredstava su osnovni uzrok zbog čega je realizirana novogradnja cesta značajno ispod preporučenog minimuma. Potrebno je značajno intenzivirati izgradnju šumskih kamionskih cesta, posebice obratiti pozornost na šumskogospodarska područja u kojima se skoro nikako nije gradilo. S obzirom da su parametri za utvrđivanje otvorenosti šuma uzeti iz okruženja, potrebno je provesti detaljniju analizu konkretnih utjecajnih čimbenika za ovaj prostor kako bi se odredio minimum i optimum.. Neophodno je u planskim dokumentima razraditi otvorenost šuma ili određenim studijama analizirati sve čimbenike koji utječu na otvorenost šuma, kako bi se postigli optimumi gustoće mreže šumskih kamionskih cesta za različite reljefne uvjete. Razvoj katastra postojeće šumske ceste je preduvjet za provođenje analize i dobivanje kvalitetnih programa otvaranja šuma. U radu je prikazana otvorenost šuma i šumskog zemljišta primarnom mrežom cesta u Republici Srpskoj. Podaci su prikupljeni GARMIN Oregon 600 GPS uređajima, na cijelom području, čiji je korisnik JPŠ “Šume Republike Srpske”, a snimljeni tragovi uspoređivani su i korigirani ortofoto snimkama rezolucije $0.50 \mathrm{~m}$. Za obradu podataka korišteni su GIS softveri, ArcGIS 10.2 i QGIS 2.16. GPS tragovi su razvrstani na javne i šumske ceste. Otvorenost šuma i šumskog zemljišta je prikazana po kategorijama šuma.

KLJUČNE RIJEČI: šumske ceste, primarno otvaranje šuma, gustoća primarne šumske prometne infrastrukture, registar primarnih šumskih prometnica, GPS, GIS, Republika Srpska 